\title{
Blueberry eye: acquired total anterior staphyloma
}

\author{
Rohan Bir Singh, ${ }^{1}$ Sahil Thakur, ${ }^{2}$ Kanwar Partap Singh ${ }^{3}$
}

${ }^{1}$ Department of Ophthalmology, Harvard Medical School, Boston, Massachusetts, USA

${ }^{2}$ Department of Ophthalmology, Government Medical College and Hospital, Chandigarh, India ${ }^{3}$ Department of Ophthalmology, Dayanand Medical College and Hospital, Ludhiana, Punjab, India

\section{Correspondence to} Dr. Rohan Bir Singh, dr.rohandhaliwal@gmail.com

Accepted 8 February 2018

\section{DESCRIPTION}

A 51-year-old woman presented to the ophthalmology emergency room with inability to close the eyelid, severe pain and light sensitivity in the left eye. Ocular examination showed severe conjunctival injection, deep corneal vascularisation, and extremely thin and protruded cornea, measuring $12 \times 14 \mathrm{~mm}$, with iridocorneal adhesions (figure 1A). The protruded lesion had a typical blueberry-like external appearance, due to the iris plugging the perforated ulcer. The patient's best corrected visual acuity (BCVA) was reduced to hand motion in the left eye and was 20/40 in the right eye, with the intraocular pressure within the normal range in both eyes. The patient was previously diagnosed with fungal keratitis following trauma but was non-compliant with topical antifungal agents and did not maintain a proper follow-up. A sclerokeratoplasty using a $14 \mathrm{~mm}$ corneal graft, as well as iridectomy and lensectomy, was performed in her left eye. The corneal graft remained clear at 4-week follow-up, and her BCVA improved to 20/100 after aphakic correction (figure 1B).

The patient was diagnosed with acquired total anterior staphyloma, a rare anterior segment

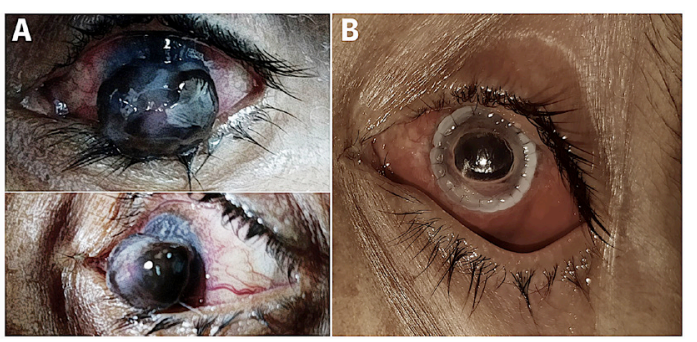

Figure 1 (A) The lesion had a typical blueberry-like external appearance, consisting of an extremely thin and protruded cornea, measuring $12 \times 14 \mathrm{~mm}$, with iridocorneal adhesions. (B) The patient underwent sclerokeratoplasty using a $14 \mathrm{~mm}$ corneal graft, as well as iridectomy and lensectomy. The graft remained clear at 4-week follow-up, and the patient's best corrected visual acuity improved to 20/100 after aphakic correction. pathology that occurs due to protrusion of uveal tissue through a prominent defect in the cornea or sclera, as a consequence of trauma, corneal ulcers, vitamin A deficiency, or congenitally as component of Peters anomaly. ${ }^{1}$ Typically the incidence of acquired anterior staphyloma is seen in low-income/ middle-income countries as a result of non-availability of proper care post trauma, in cases of infectious keratitis or due to poor patient compliance to treatment. $^{2}$

\section{Learning points}

Patients at a high risk of ocular surface infections post trauma should be encouraged for a regular follow-up at short intervals of time.

- The attending ophthalmologist should ensure compliance of the prescribed regimen of drugs to prevent deterioration of infective keratitis.

- A surgical intervention, if required, should be performed at an early stage to salvage as much ocular surface tissue as possible and prevent complications such as staphyloma.

Contributors RBS and ST diagnosed the case. RBS and KPS wrote the manuscript. ST was actively involved in the patient's surgical management.

Funding This research received no specific grant from any funding agency in the public, commercial or not-for-profit sectors.

Competing interests None declared.

Patient consent Obtained.

Provenance and peer review Not commissioned; externally peer reviewed.

(C) BMJ Publishing Group Ltd (unless otherwise stated in the text of the article) 2018. All rights reserved. No commercial use is permitted unless otherwise expressly granted.

\section{REFERENCES}

1 Grieser EJ, Tuli SS, Chabi A, et al. Blueberry eye: acquired total anterior staphyloma after a fungal corneal ulcer. Cornea 2009;28:231-2.

[please include Day Month

Year]. doi:10.1136/bcr-2018 224271
2 Panda A, Sharma N, Angra SK, et al. Sclerokeratoplasty versus penetrating keratoplasty in anterior staphyloma. Ophthalmic Surg Lasers 1999;30:31-6. 
Copyright 2018 BMJ Publishing Group. All rights reserved. For permission to reuse any of this content visit http://group.bmj.com/group/rights-licensing/permissions.

BMJ Case Report Fellows may re-use this article for personal use and teaching without any further permission.

Become a Fellow of BMJ Case Reports today and you can:

- Submit as many cases as you like

- Enjoy fast sympathetic peer review and rapid publication of accepted articles

Access all the published articles

- Re-use any of the published material for personal use and teaching without further permission

For information on Institutional Fellowships contact consortiasales@bmjgroup.com

Visit casereports.bmj.com for more articles like this and to become a Fellow 